症例

\title{
重複癌36例の検討
}

\author{
広島大学第 2 外科 \\ 中 塚博文黑朾義則 奥道佰 大 \\ 西亀正之江崎治夫
}

\section{A STUDY ON 36 PATIENTS WITH MULTIPLE PRIMARY MALIGNANT NEOPLASMS}

Hirofumi NAKATSUKA, Yoshinori KURODA, Tsuneo OKUMICHI, Masayuki NISHIKI and Haruo EZAKI

2 nd Department of Surgery, Hiroshima University School of Medicine, Hiroshima

われわれは1968年から1980年12月までに，36例の重複癌症例を経釦した．5ち1例は 3 重複癌で, 他は全て 2 重複癌であった。また 8 例は広島での原爆被爆者であった。

重複癌の判定はWarren およびGates の定義を採用し，第 1 癌と第 2 癌の発現間隔が 1 年末满の店例を同時性, 1 年以上を異時性とした. 15例が同時性, 21例が異時性であっ た。

教室において，上記13年間における悪性腫瘍店例のうち，大腸201例中11例（5.5\%）, 甲状腺 253 例中 12 例 $(4.7 \%)$ 肺 181 例中 8 例 $(4.4 \%)$ 乳腺166例中 5 例 $(3.0 \%)$ 胃619例 中12例 $(2.0 \%)$ に重複癌を認めた。

好発年齢は男性70歳代, 女性60歳代で, 男女比は1：1.4で女性に多かった。

発現間隔は平均 4 年 3 カ月で，男女別では女性に長い傾向がみられた。 主た原爆被爆 者 8 例の平均が 6 年10力月と長かった。

葴器別症例数は，第 1 癌では甲状腺 7 例，子宮 4 例，乳腺 3 例で消化器系は胃 4 例, 大腸 4 例であった。一方第 2 癌では，胃 7 例，大腸 7 例，食道 2 例，肝 1 例，膵 1 例と 消化器系が多く全体の50\%を占め，また肺 6 例，甲状腺 5 例であった。

第 1 癌と第 2 癌の租み合わせは，同一系統䁖器に多い特徽は認められなかった。 な打 36 例中 25 例 $(69 \%)$ に消化器系の癌の関与を認めた。

予後は単発癌に比べ特に不良とは言えず，異時性が同時性よりやや良好であった。

悪性腫瘍の発生機序としては，発癌物質や発癌ウィルス，放射線等の外来性の刺激と， 遭层, 体質, 免疫などの宿主側の因子が考えられ, 種々の検討が行なわれているのが現 状である.

われわれは，重複癌36例中 8 例に広島での原爆被爆者を認めたので，これらを含め若 干の文献的考察を加光報告した。

\section{緒}

近年, 悪性腫瘍に対する診断技術, 治療法の進歩向 上，また平均寿命の延長により，同一個体に重複して 発生する悪性腫場の報告が増加している。

1879年に Billroth' ${ }^{1}$ がはじめて重複癌症例を報告し
て以来, 現在その判定基準としては, 1932年にWarren

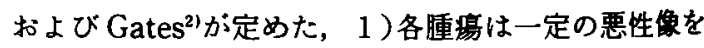
示し，2）相互に離れた部位に存在し，3）一方が他 方の転移でないという criteriaが一般によく用いられ ている. 
われわれは, 1968年から1980年12月までの13年間に, 36例の重複癌症例を経験し，またこのうちの 8 例に, 広島での原爆被爆者を認めたので，これらを含め若干 の文献的考察を加兄報告する。

\section{1. 症例}

重複癌の判定基準はWarrenおよび Gatesの定義 を採用した。たたし同一臓器に発生した多発性の癌は， 判定困難な症例が多く除外した，発現間隔については 1 年末满の症例を同時性, 1 年以上の症例を異時性と した，重複癌症例36例中，同時性が15例，異時性が21 例であった。また 1 例のみが 3 重複癌で，他は全て 2 重複癌であった。

\section{2. 成 績}

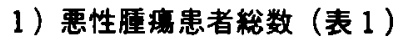

1968年－1980年12月までの13年間に，教室における 悪性腫場患者数の合計は1757例で，また主な葴器別症 例数としては，胃癌619例，甲状腺癌253例，大腸癌201 例, 肺癌181例, 乳癌166例の順になっている。

\section{2 ) 重複癌発生数と発生部位}

上記13年間の重複癌症例は36例で，悪性腫瘍患者総 数に対し， $2.1 \%$ 割合であった。また，この期間にお ける悪性腫瘍患者総数之重複癌症例数の年度別推移を みてみると, 明からな重複癌症例の增加傾向を認める (図 1)

つぎに発生部位としては（表 2 ）第 1 癌では消化器 采以外では甲状腺 7 例，子宮 4 例，乳腺，膀胱，皮席 がそれぞれ 3 例で多くを占め，一方消化器系は胃 4 例， 大腸 4 例で，36例中 8 例（22\%）であった。第 2 癌で は, 胃 7 例, 大腸 7 例, 食道 2 例, 肝 1 例，羘 1 例と

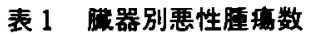

\begin{tabular}{|c|c|c|c|}
\hline 臓 & 器 & 症 例 数 & \\
\hline 胃 & 癌 & 619 & $35.2 \%$ \\
\hline 甲 状 腺 & 癌 & 253 & $14.4 \%$ \\
\hline 大 腸 & 癌 & 201 & $11.4 \%$ \\
\hline 肺 & 癌 & 181 & $10.3 \%$ \\
\hline 乳 & 癌 & 166 & $9.5 \%$ \\
\hline 膵 & 癌 & 84 & $4.8 \%$ \\
\hline 道 & 癌 & 77 & $4.4 \%$ \\
\hline 食 & 癌 & 65 & $3.7 \%$ \\
\hline 肝 & 癌 & 23 & $1.3 \%$ \\
\hline そ & 他 & 88 & $5.0 \%$ \\
\hline 計 & & 1757 & $100.0 \%$ \\
\hline
\end{tabular}

広大 2 外科(1968 1980 年)

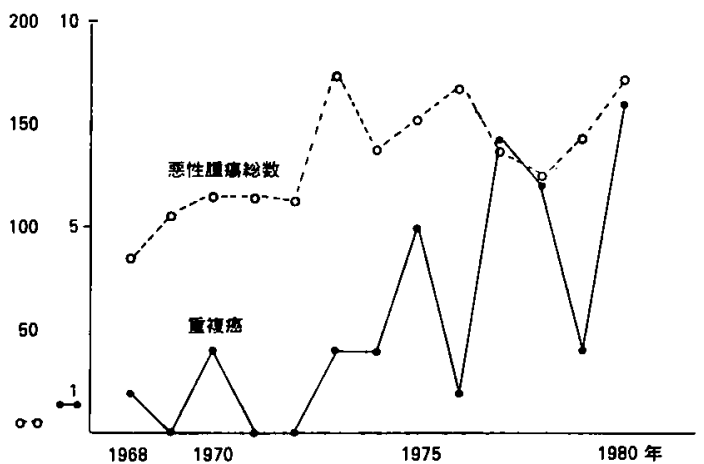

图 1 当科における重復螘の年度別推移(広大 2 外科)

表 2 重複癌の発生部位別症例数

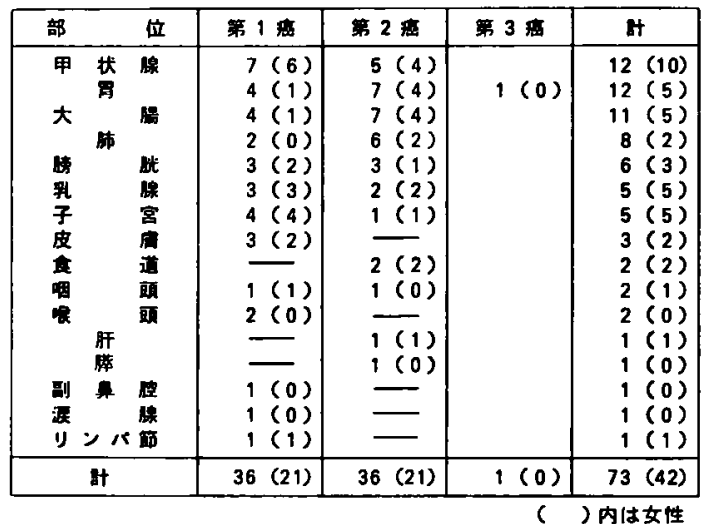

消化器系が多く全体の50\%を占め, その他, 肺 6 例, 甲状腺 5 例，膀胱 3 例であった。 また第 3 癌は胃が 1 例であった。

\section{3）年龄，性別分布（図 2)}

重複癌の第 2 癌発見時の平均年龄は62.6歳で男性 64.3歳，女性61.3歳であった。また，年龄分布は50歳 代 6 例 (16.7\%)，60歳代11例（30.1\%）70歳代13例 (36.1\%)で，高齡になるに従って症例数が多くなって いる。亦た，同時性 15例の平均が58.0歳，異時性21例 の平均が65.8歳であった。なお，最高齢者は78歳の男 性，最年少者も37歳の男性であった。

つきに，男女比では，男性15例(41.7\%)，女性21例 (58.3\%)と女性に多かったか，発現間隔で比較してみ ると，同時性では，男性 8 例，女性 7 例でむしろ男性 に多く，異時性では，男性 7 例，女性14例で，女性が 2 倍となっていた。

\section{4 ）発現間隔（表 3）}

重複癌36例の平均発現間隔は 4 年 3 カ月であるが, 男女を比較すると，男性では 5 年以上が 15 例中 2 例 


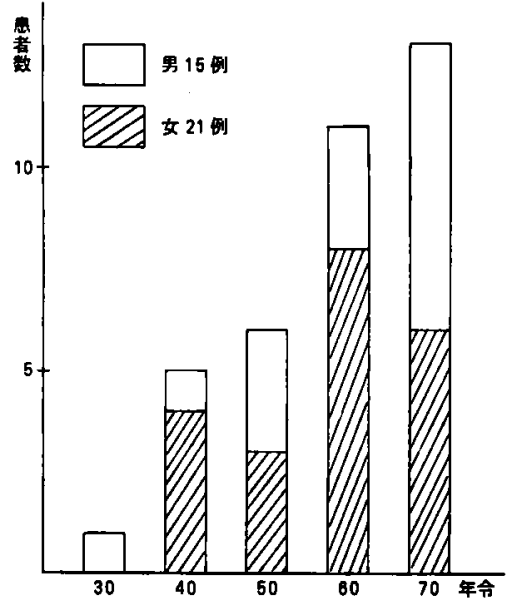

図 2

表 3 重複糔の男女別発現間隔

\begin{tabular}{|c|c|c|c|}
\hline 発現間隔 & 男 & 女 & 計 \\
\hline 1 年末満 & 8 & 7 & 15 \\
\hline$\sim 5$ 年 & 5 & 6 & 11 \\
\hline$\sim 10$ 年 & 2 & 2 & 4 \\
\hline 10 年以上 & 0 & 6 & 6 \\
\hline 計 & 15 & 21 & 36 \\
\hline
\end{tabular}

（13.3\%)であるのに比し，女性は21例中 8 例(38.1\%) となって拈り，女性に長い傾向がみられる。なお，最 長は76歳の女性で第 1 癌が子宮癌, 第 2 癌が甲状腺癌
で，間隔は18年であった。

\section{5) 脸器別組み合わせ（表 4)}

葴器別組み合わせについては，大腸と膀脱, 甲状腺 と子宮の組み合わせがそれぞれろ例，また甲状腺と大 腸, 甲状腺と肺，大腸之肺，胃と乳腺，胃之喉頭を 2 例つつ認めるのみで他の組み合わせは 1 例つうであっ た。 また, 消化器系同志の組み合わせは 4 例のみで, 同一系統臓器に多い特微は認められなかった。

\section{6) 予媵}

重複癌36例中, 第 2 癌治療後 3 年以上観察し得た症 例についてその生存率をみると，同時性が 6 例中 3 例 (50\%)，異時性かi14例中 8 例 $(57.6 \%)$ であり，また 同様に 5 年生存率では，同時性が 3 例中 1 例(33.3\%) 異時性が 9 例中 6 例（66.6\%）で，異時性が比較的良 好であった。 また，最長生存例は甲状腺癌と胃癌の組 み合わせの女性で10年 1 カ月であった。

\section{7 ）原爆被爆者の重被盘（表 5 ）}

重複癌36例中, 8 例が広島での原爆被爆者であった。 8 例中 5 例の被爆地が爆心地より $2 \mathrm{~km}$ 以内のいわゆ る近距離被爆者であった。男女比は $3 ： 5$ で女性に多 く，年龄分布は，最年少 40 歳，最高龄76歳で平均 63.8 歳であった。 また。発現間隔は平均 6 年10カ月と長かっ た. 缄器別発生数は甲状腺 4 例, 大腸 3 例, 子宮 3 例, その他はそれぞれ 1 例つつであった．眮器別組み合わ せは，甲状腺と子宮の組み合わせが 2 例認められた。 予後は第 2 癌治療後 3 年以上観察し得た例についての 生存率が 7 例中 5 例（71.4\%）と良好であった。

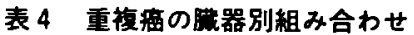

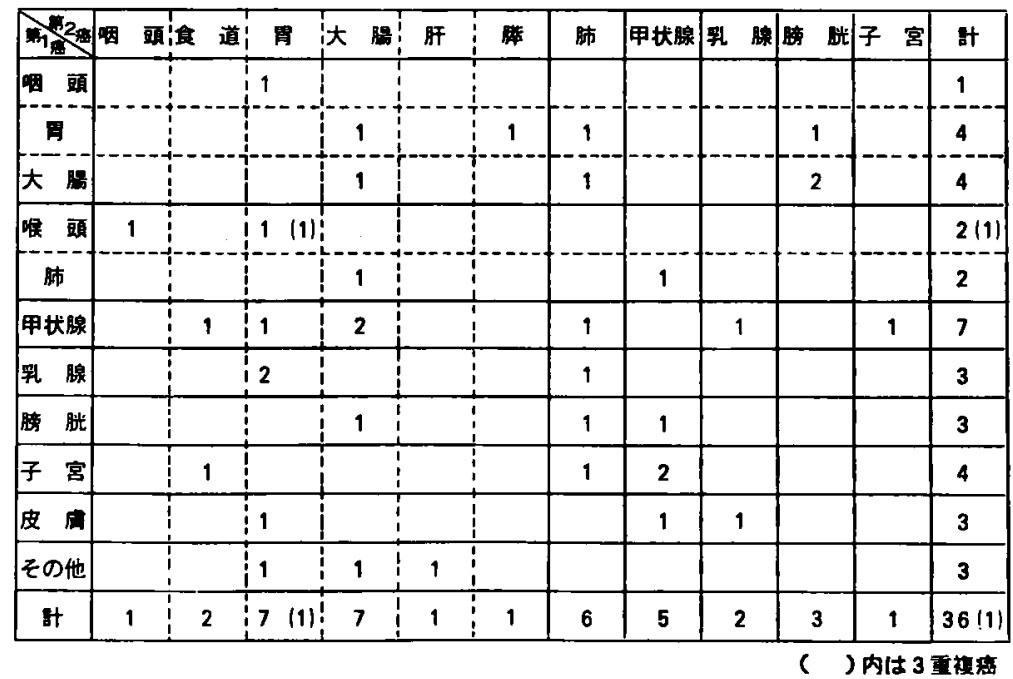




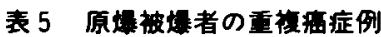

\begin{tabular}{|c|c|c|c|c|c|c|c|c|}
\hline 症例 & 年令 & 性 & 第 1 港 & 露到年䐴 & 第 2 症 & 発現間隔 & 被煴地 & 予 \\
\hline (1) & & 女 & 子宮㾇 & 1956年 & 甲状腺瘦 & 18年 & $4 \mathrm{~km}$ & 5年 7カ月死 \\
\hline (2) & 40 & 女 & 甲状腺婈 & 1963年 1月 & 㲖 癌 & 12年 & $1.3 \mathrm{~km}$ & 5年 6力月生 \\
\hline (3) & 66 & 女 & 子宮密 & 1965年12月 & 食道㿋 & 7年 2 カ月 & $1.8 \mathrm{~km}$ & 6年10力月死 \\
\hline 4 & 61 & 女 & 甲状腺癌 & 1969年 8月 & 直腸 底 & 7年 8 カ月 & $2 \mathrm{~km}$ & 2年 6力月死 \\
\hline 5 & 74 & 男 & 桔腸痘 & 1972年 2月 & 肺 & 8年 & $1.4 \mathrm{~km}$ & 1力月死 \\
\hline 6 & 53 & 男 & 皮成慧 & 1973年 6月 & 胃 & 1年 8 カ月 & $2 \mathrm{~km}$ & 5年 8力月生存 \\
\hline 7 & 72 & 女 & 甲状腺愿 & 1976年 9月 & 子宮痻 & 1 カ月 & $3 \mathrm{~km}$ & 4年 2力月生存 \\
\hline 8 & 68 & 男 & 直腸痁 & 1977年 4月 & 蒡脱 症 & 同 時 & $5 \mathrm{~km}$ & 1年 \\
\hline
\end{tabular}

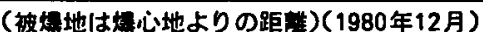

\section{表 6 重被癌の発生頻度}

\begin{tabular}{|c|c|c|c|c|c|}
\hline 湢 & 床 & 例 & 剖 & 换 & 例 \\
\hline 報 告 者 & 表年 & 頻 度 & 報 告 者 & 発表年 & 頻 度 \\
\hline 皇 $^{6}$ & 1960 & $0.59 \%$ & 崎 & 1961 & $1.56 \%$ \\
\hline$F^{7}$ & 1963 & $0.33 \%$ & 森 ${ }^{17}$ & 1963 & $2.4 \%$ \\
\hline 村 ${ }^{8}$ & 1979 & $8.1 \%$ & 林 ${ }^{11}$ & 1971 & $5.8 \%$ \\
\hline 南 $^{14}$ & 1980 & $2.1 \%$ & $\mathbf{⿴ 囗 十}^{18}$ & 73 & $2.5 \%$ \\
\hline 西 土 $\#^{\mathbf{9}}$ & 1981 & $2.3 \%$ & $上^{13}$ & 1980 & $2.80 \%$ \\
\hline Hurt ${ }^{15}$ & 1933 & $3.3 \%$ & Warren 2 & 1932 & $3.7 \%$ \\
\hline Stalker ${ }^{16}$ & 1939 & $4.5 \%$ & Fried $^{4}$ & 1958 & $1.54 \%$ \\
\hline Moertel $!^{5}$ & 1961 & $4.6 \%$ & Moertel & 1961 & $10.6 \%$ \\
\hline
\end{tabular}

考察

\section{重䙓瘦の定義}

1879年 Billroth"1は, 二つの癌がそれぞれ異なった組 維像を呈し，それそれ異なった部位から発生し，それ ぞれの転移を有する症例を重複癌として報告した。そ の後 Billrothの定義は钽密すぎるとして，1932年に Warren および Gates ${ }^{2}$ は，一方が他方の転移である可 能性が除外されれぱよいと判定基準を㹡大した，現在 この定義が一般によく用いられている。しかし，この 定義にもあいまいな点が牫されている，たとえば，同

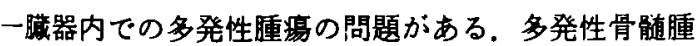
や悪性リンハ腫を一畽瘍単位とみなすのには，まず疑 問の余地はないであろう。しかし，胃や腸管，乳腺， また膀胱に複数個の独立した悪性腫蔔を認めた場合た だちに単一の悪性腫膓と考えてよいのであろ5か， Multicentric carcinogenesis はそれだけで，大きな問 題であり，今回われわれは，同一䁍器内に発生した複 数䁬の癌は“多発癌”として一応除外した。

\section{重複癌の発生頻度（表 6)}

悪性腫瘍に対する重複癌の発生頻度は，欧米の報告 では, Warren ${ }^{2} 3.7 \%$, Watson ${ }^{3 / 2}$.5\%, Fried ${ }^{4} 1.54 \%$, Moertel $^{51} 4.6 \%$ (臨床例)， $10.6 \%$ (剖検例)なってお り，また本邦においてては，臨床例で，北畠的 $0.59 \%$ ，山 下7) $0.33 \%$ ，龍村8 $8.1 \%$ ，西土井 $2.3 \%$ ，剖検例では， 赤崎 ${ }^{101} 1.56 \%$, 若林 ${ }^{11} 5.8 \%$ ，森田 ${ }^{12} 3.3 \%$ ，中

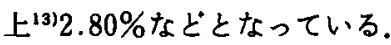

以上のごとく報告者によりかなりの頻度の差が認め られるが、これは採用した定義，報告年代，臨床例か， 剖検例か，また各施設が取り扱ら悪性腫湯の種類，さ らには治療方法等に起因しており，母集団の統計処理 により大きな差異となっている。

年度別重複癌発生頻度：教室における重複癌症例に は最近増加傾向が認められるが，剖検例で信頼度の高 い日本病理剖検輯報により1960年〜1977年までの18年 間の重複癌症例の発生頻度を年度別に集計し，加えて 総人口に対し65歳以上の占める割合を厚生白書により 調查した(図 3). 全悪性腫瘍症例に対する重複癌の比 率は，1960年1.0\%，1965年1.2\%，1970年3.0\%，1975 年3.9\% と着実に增加している。また同様に総人口に対 する65歳以上のいわゆる高龄者の占める割合も1960年 $6.8 \%$ から1977年 $8.4 \%$ へと明らかな渐増傾向を示して いる.

このような近年におけす重複癌発生頻度の増加は， 悪性腫嫊に対する診断技術，治療法の進歩向上により 長期生存例の増加， また平均寿命の延長による高龆者 の増加等に起因していると思われる。 また第 1 癌に対 する治療としての抗癌剤の投与, 放射線照射が逆に第 


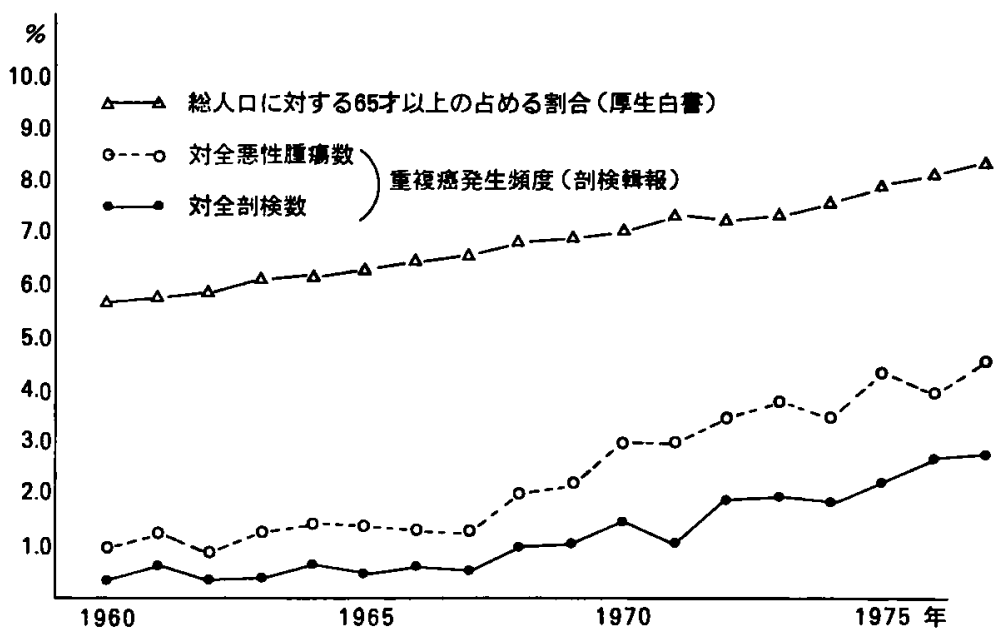

図3重萑瘏発生率と総人口に対する65藏以上の占める割合の年度別推移

2 癌の発生に影暗を与えているとの報告19120121) ああ り，今後の検討が待たれる。

缄器別発生頻度：教室における重複癌の主な葴器別 発生数と悪性腫症例数に対寸る割合は, 大腸201例中11 例 $(5.5 \%)$ ，甲状腺，253例中12例 $(4.7 \%)$ 肺181例中 8 例 $(4.4 \%)$ 乳腺166例中 5 例 $(3.0 \%$ ) 胃619例中 12 例 (2.0\%) となっている。

蔵器別発生頻度に関する報告22)23)は多数行なわれて いるが，剖検例と臨床例においてかなりの差が認めら れる。平田 ${ }^{18)}$ は, 日本剖倹輯報を用い1966年〜1971年の 6 年間の集計を行なっているが，癌症例に対する重複 癌症例の頻度の高い臓器として, 甲状腺 $26.2 \%$, 前立 腺 $15.7 \%$, 咽頭13.3\%，皮庙13.1\%等をあげている。 またこれに続くものとして，腎10.7\%，大腸 $7.5 \%$, 膀 脱 $6.5 \%$ ，子宮 $6.4 \%$ ，乳腺6.1\%，また胃は4.5\%と報 告している。しかし甲状腺, 前立腺には潜在癌が含ま れていることを考虑すべきであるとしている，また， 山下7は，1963年に癌研放射線科での臨床例を報告し ているが，結腸 $5.9 \%$, 卵巣 $3.2 \%$ 咽頭 $1.7 \%$, 甲状腺 $1.6 \%$, 上顎 $1.4 \%$, 胃 $1.3 \%$, 直腸 $1.2 \%$ が比較的高頻 度の咸器となっている.最近, 犬塚 ${ }^{25)}$ ら大腸と合併す る重複癌症例に増加㑯向があると報告しており今後の 推移に興味がすたれる。

\section{重椱湿の年魿別分布}

重複癌の好発年龆については一般に50歳〜60歳代に peak があるとの報告(10)14が多いが，教室の症例では 平均年龄62.6歳で，男性は70歳代，女性は60歳代が最
も多く，全体としては60歳以上が36例中24例(66.7\%) を占めていた。

以上のごとく重複癌の好発年龄は一般の悪性腫瘍に 比へ，やや高年龄層にずれており，女性は男性より若 年傾向を認めるが，このことは加龄が重複癌発生に影 響を与えているものと思われ，また性差については女 性には，乳癌，子宮癌，甲状腺癌なと比較的若年者に 好発し，予後も良好な癌との合併がかなり存在する為 と思われる，男女比に関しては，北畠は $3 ： 2$ ，赤䗁 は1.64：1，中上は1.7：1, Moertel は1.6：1と男性 が高率となっている報告が大部分であるが Warren は 3：5 平田は 1：2 と女性の多い報告むある. 教室 の㱏例では 1：1.4と女性が多かったが，全悪性腫場 中, 甲状腺癌, 乳癌の占める割合が高く，当施設の特 改があらわれていると考えられる。

\section{重複癌の発現間隔}

重複癌を発現間隔により，同時性，異時性と分類し ているが，これは便宜上の基準である。間隔も山下は 1 カ月, Moertel は 6 カ月, 西は 1 年末満を同時性とし ており，一定ではない，教室の症例については一応1 年末满を同時性として報告した。教室における平均発 現間隔は 4 年 3 力月であるか，男女別に比較してみる と, 男性15例の平均が 2 年 2 力月で女性 21 例の平均かi 5 年11カ月であった。 また馬場, 阿南、西土井らの報 告です，女性の発現間隔が長くなっている.

次に教室の症例には 8 例の広島での原爆被爆者が含 まれているが，この8例の発現間隔の平均は 6 年10力 
月と長くなっている。 またこのうち 3 例は第 1 癌に対 し，放射線治療が行なわれているか，この3 例の発現 間隔の平均が12年 5 力月と，とくに長くなっている。

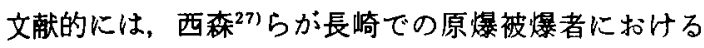
重複癌症例の報告を行なっているか，被爆者は非被爆 者に比へ，発現間隔が 6 力月以上の異時性の症例が多 いと述べている.

また，放射線治療歴を有する重複癌症例を三橋 ${ }^{28)} ら$ が報告しているが，第 2 癌の発生部位が放射線治療部 位と一致する 22 例の発現間隔の平均が14.7年であるの に比し，照射部位と第 2 癌の発生部位が異なっている 12例の平均は 5.8 年であったとしている.

教室での症例数は少ない為, 推測の域をでないか， 放射線被爆が第 2 癌誘発に何らかの影響を与えている ものと思われる。また少なくとも臨床医は，被爆歴を 有する人々に対しては, 発癌を念頭において長期の経 過観察を続ける必要があると思われる。

\section{重複癌の組み合わせ}

重複癌の組み合わせについては, $\operatorname{Cook}^{291}$, 中村ら ${ }^{301}$ が詳細な報告を行なっているが，Cookは，1940年 ～1963年の23年間における393例の重複癌症例を検討 し, 肺と喉頭, 膀胱尿管之前立腺, また女性性器相互 といった解剖学的あるいは内分泌学的に関連した藏器 間の組み合わせが多いと報告している、中村らは, 1958 年 1969年の 12 年間について日本剖検輯報より 1.121 例の重複癌を抽出し，その組み合わせを検討している が, 本邦では一般の単発癌の発生頻度を反映して消化 器系の組み合わせ, 中でも胃癌との合併が多く、続い て肺癌, 甲状腺癌, 食道癌, 子宮癌, 肝癌等との合併 が多いとしている。しかしCookの設定した pairing を肯定する相関関係は認めら㧈なかったとしている。

教室の症例でも，同一系統缄器に多い特微は認めら れなかったか，36例中25例（69\%）に消化器系の癌が 関与していた。 また，甲状腺癌との合併が36例中12例 (33\%)と多かった。

\section{重䙓癌の発生機転}

覀性腫煬の発生機序としては，発癌物質や発癌ウィ ルス，放射線等の外来性の刺激と，遺云，体質，免疫 などの宿主側の因子が考えられる。重複癌の検討は， この複雑な発癌のメカニズムに何らかの示唆を与える ものとして注目されている。

われわれは 8 例の原爆被爆者重複癌を経験し, 外来 性刺激の 1 つである放射線の影響について若千の情報 を得たか，浜田 ${ }^{311}$, 若林ら ${ }^{11}$ は厇島での原爆被爆者, ま
た西森ら 271 長崎での被爆者を検討し，非被爆者と比 較して重複癌の発生率が高いと報告している.

また, Moertel らは Mayo Clinic において1944年 〜 1953年の 10 年間に経験した 1,909 例の重複癌症例を 報告しているが，その中で，第 1 癌に対する化学療法, 放射線療法, 外科的療法が, 第 2 癌を誘発する可能性

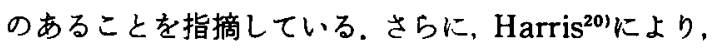
“抗癌剂”の発癌性について報告がなされており, 興味 深い.

一方, Tondreau ${ }^{32}$, 赤崎 ${ }^{10)}$ は重複癌患者の体質的 因子を重要視して扣り，また Lynch $^{33)} ら は$ 癌家系の詳 細な症例報告を行なっているか，教室の症例において は，36例中 13 例 $(36.1 \%)$ に 3 親等以内の癌の家族歴 を認めている。

最近, 重複癌患者の免疫能に関する研究が行なわれ つつある。しかし Dellon ${ }^{35)} ら は 42$ 例の重複癌症例につ いて HL-A study を行なったが特定の組織適合抗原の 保有者に多いという有意の差は得られなかったと報告 している.しかし，現在進歩の著るしい研究分野であ り.さらに進んだ娭討が期待される.

また $\mathrm{Spratt}^{36}$ ららは重複癌の発生を単に加龄現象之 関連づけているが，現在日本の人口構成は高龄者が増 加する傾向にあり，わが国においても関心の深い事項 である.

\section{結語}

1) 教室において1968年〜1980年12月までに36例の 重复癌症例を経験した。5ち8例が，広島での原爆被 爆者であった。この期間における悪性腫湯患者総数は 1,757 例で, 重複癌症例は総数の $2.1 \%$ の頻度であった。

2) 葴器別頻度では大腸, 甲状腺, 肺に発生率が高 かった.

$3 ）$ 好発年龄は男性70歳代, 女性60歳代で, 男女比 は1：1.4で女性に多かった。

4) 発現間隔は同時性15例，異時性21例で，平均 4 年 3 カ月であった，男女別には女性に長い傾向がみら 九, また原爆被爆者 8 例の平均か～ 6 年10力月と長かっ た.

5) 組み合わせには同一系統臟器に多い特徽は認め られなかった。 なお，36例中25例（69\%）に消化器系 の癌の関与を認めた。

6）予後は単発癌に比べ, 特に不良とは言光ず，異 時性が同時性よりやや良好であった。

7) 各癌疾患に対する治療成績の向上，また高齢者の 増加により, 重複癌発生率の上昇が今後予想される。 
臨床医は第 1 癌の治療に際し，常に次発癌発生を念頭 において放射線療法，化学療法，免疫療法を施行すべ きである。

なお，本論文の要旨は第43回日本臨床外科医学会総会に おいて発表した。

\section{文献}

1) Billroth, C.A.T.：［文献 2）ょり引用]

2) Warren, S. and Gates, O.: Multiple primary malignant tumors. A survey of the literature and a stastical study. Amer. j. Cancer, $16: 1358$ $-1414,1932$.

3) Watson, T.A.: Incidence of multiple cancer. Cancer, 6: 365-371, 1953.

4) Fried, B.M. : Primary multiple cancers. Arch. Surg., $77: 730-741,1958$.

5) Moertel, C.G., Dockerty, M.B. and Baggenstoss, A.H. : Multiple primary malignant neoplasms. Cancer, $14: 221-247,1961$.

6）北畠 隆，金子昌生，木戸長一郎他：重複要性腫 瘍の発現頻度に関して，癌の蹦床，6：337-345, 1960.

7）山下久雄，網野三郎，五味 諴他：多発性原発性 墨性腫晹，特に重複癌について，臨床放射線，8： $797-806,1963$

8）龍村俊樹, 瀬川安雄, 中川正昭他：当院に抽ける 重複癌症例の検討，癌の臨床，25：1126-1130， 1979.

9）西土井英昭, 岡本恒之, 木村 修他：重複癌60例 の臨床的検討，癌の臨床，27：693-697，1981。

10）赤崎兼義，若狭治媇，石館卓三：原発性重複癌に ついて, 日本臨床，19：1543-1551，1961.

11）若林俊郎，井 洋平：多発性腫瘍の研究，日本公 衆㽞生雑誌, $18 ： 251,1971$.

12）森田豊彦：一般剖検における重複癌と肺癌を含む ものの検討, 癌の臨床, $23: 1033-1041 ， 1977$.

13）中上和彦，井藤久雄，暒原博毅他：三重複癌の 1 剖倹例。広島医学, $33: 1059-1065,1980$ 。

14）阿南敏郎, 宮部雅次, 过秀男：当科に打ける重 複癌31例の検討，外科診療，22：697-701，1980.

15) Hurt, H.H. and Broders, A.C.: Multiple primary malignant neoplasms. J. Lab. Clin. Med., 18: 765-773, 1933.

16) Stalker, L.K., Phillips, R.B. and Pemberton, J. J.: Multiple primary malignant lesions. Surg. Gynec. \& Obst., 68 : 595-602, 1939.

17）森亘，足立山夫，岡辺治男 他：悪性腫浯剖検
例755例の解析, 癌の臨床, 9：351-374， 1963.

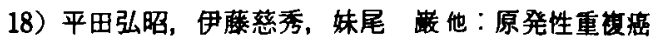
につい, Medical postgraduates, 13: 498-508, 1975.

19) Chabner, B.A.: Second neoplasm, - A complication of cancer chemotherapy. The New Engl. J. of Med., 294 : 213-214, 1977.

20) Harris, C.C. : The carcinogenecity of anticancer drugs. Cancer, 37: 1014-1023, 1976.

21) Hutchison, G.B. : Late neoplastic changes following medical irradiation. Cancer, 37: 1102 $-1107,1976$.

22）表原多文，大城久司，中川研一他：重复癌一胃癌 と他腀器癌との重複例, 広島医学, 31：776-780, 1978.

23）丸林誠二, 藤原博, 砂川保幸他：甲状腺癌と合 併した他荿器重複癌, 癌の臨床, $23 ： 14-19.1977$.

24）犬塚貞光, 高野平八郎，平濛隆三他：重複虎の問 題点，外科，39:779-786，1977.

25) 西 满正, 関 正威：重復腫湯の問題点一とくに 胃癌を中心としての考察，医学のあゆみ，80： 188-192, 1972.

26）馬場謙介, 下里幸雄, 渡辺 漸他：重複煰の統計 とその問題点, 癌の臨床，17:424-436，1971.

27）西森一正，宮崎純一，渑口健郎他：長崎における

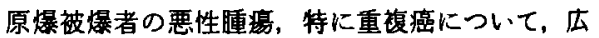
島医学, $33: 298-305,1980$.

28）三桥紀夫，伊藤 潤，新部英男：重複㣫埸と照射 歴との関連について，日本医学放射楾学会哧誌， $39: 243-251,1979$.

29) Cook, B.G. : A comparison of single and multiple primary cancers. Cancer, $19: 956-966,1966$.

30）中村恭二，相沢 幹：組々合せ上りみた重複癌の 検討, 癌の臨床, $18: 662-666,1972$.

31）捠田忠雄，石田 定：被爆者にみられた重复癌に ついて, 長崎医学会雜誌, 47：311-318， 1972.

32) Tondreau, R.L.: Multiple primary carcinomas of the large intestine. Amer. J. Roentgenol., 71 : 794-807, 1954.

33) Lynch, H.T. and Krush, A.J.: Differential diagnosis of the cancer family syndrome. Surg. Gynec. \& Obst., 136 : 221-224, 1973.

34）藤井俊宏, 西亀正之, 奥道佰夫他：肺と他搭器上 の重複癌症例の検討, 日本胸部臨床, 40 ： 744-749, 1981.

35) Dellon, A.L., Chretien, P.B., Claude Potvin, et 
al. : Multiple primary malignant neoplasms. A search for an immunogenetic basis. Arch. Su. rg., $110: 156-160,1975$.
36) Spratt, J.S. and Hoag, M.G.: Incidence of multiple primary cancers per Man-Year of follow up. Ann. Surg., 164 : 775-784, 1966. 